\title{
Creation of Mo active sites on indium oxide microrods for photocatalytic amino acid production
}

\author{
Mang Zheng ${ }^{1}$, Qi Li ${ }^{2}$, Mingyang Liu ${ }^{2}$, Jianan Liu ${ }^{1}$, Chen Zhao ${ }^{3}$, Xudong Xiao ${ }^{1}$, Hongli Wang ${ }^{1}$, Jing Zhou ${ }^{5}$, \\ Liping Zhang ${ }^{4^{*}}$ and Baojiang Jiang ${ }^{1^{*}}$
}

\begin{abstract}
As an n-type semiconductor, $\operatorname{In}_{2} \mathrm{O}_{3}$ is considered a promising photocatalyst for producing amino acids using biomass derivatives as precursors. However, similar to other intrinsic semiconductors, $\operatorname{In}_{2} \mathrm{O}_{3}$ suffers from poor charge dynamics. Herein, we show the synthesis of Mo-doped $\operatorname{In}_{2} \mathrm{O}_{3}$ $\left(\mathrm{Mo}-\mathrm{In}_{2} \mathrm{O}_{3}\right)$ with a porous rod-shaped structure through a onestep solvothermal reaction followed by calcination. Under visible-light irradiation, $\mathrm{Mo}-\mathrm{In}_{2} \mathrm{O}_{3}$ achieves a high conversion rate of $81 \%$ for the reaction that transforms lactic acid into alanine with a selectivity of $91 \%$. Spectroscopic techniques and density functional theory calculations reveal that Mo doping introduces defect states slightly below the conduction band of $\mathrm{In}_{2} \mathrm{O}_{3}$, which improves the separation of photogenerated electron-hole pairs. In addition, Mo atoms on the surface form extra adsorption and reaction centers that greatly enhance the reaction rate. This work provides insights into the development of transition metal-doped semiconductor photocatalysts to produce amino acids.
\end{abstract}

Keywords: photocatalysis, $\operatorname{In}_{2} \mathrm{O}_{3}$, transition metal doping, charge transfer, organic synthesis

\section{INTRODUCTION}

Amino acids are organic compounds containing amino and carboxyl groups. They are not only regarded as the cornerstones of life but also widely used in the production of medicines, polymer materials, and pesticides [1-3]. The broad applications of amino acids in human activities necessitate efficient synthetic strategies [4-6]. However, as a traditional method, chemical synthesis suffers from many shortcomings, such as the use of toxic cyanide and harsh reaction conditions $[7,8]$. Therefore, heterogeneous catalysis has been explored. For example, Wang et al. [9] reported the direct conversion of lactic acid (LA) derived from lignocellulosic biomass into $\alpha$-amino acids using ruthenium-containing nanoparticles supported by carbon nanotubes. In addition, Deng et al. [10] prepared $\mathrm{Ru}_{1} \mathrm{Ni}_{7} / \mathrm{MgO}$ by wet impregnation, which was used to convert crude glycerol to LA via a two-step process. By contrast, the newly developed synthetic methods, which use biomass as the precursor, are more advantageous. Nevertheless, harsh conditions are necessary to drive the reaction, including high temperature [11].

Recently, photocatalysis that uses semiconductors such as $\mathrm{TiO}_{2}$ [12,13], $\mathrm{CuO}$ [14], $\mathrm{C}_{3} \mathrm{~N}_{4}$ [15-18], $\mathrm{ZnIn}_{2} \mathrm{~S}_{4}$ [19], and $\mathrm{In}_{2} \mathrm{O}_{3}$ $[20,21]$ has witnessed great progress in the application of organic synthesis. This technology generates electrons and holes to induce redox reactions under mild conditions, making it suitable for the production of amino acids [22]. For example, Song et al. [23] reported the conversion of biomass-derived LA into an amino acid over CdS excited by visible-light illumination. In the photocatalytic production of amino acids, the design and synthesis of effective catalysts are considered a key challenge. $\mathrm{In}_{2} \mathrm{O}_{3}$, which is an n-type semiconductor, has excellent stability and efficiency in organic synthesis involving small molecules and photocatalytic $\mathrm{CO}_{2}$ reduction [20,21,24-27]. However, similar to most unmodified semiconductor photocatalysts, $\mathrm{In}_{2} \mathrm{O}_{3}$ suffers from low separation efficiency of photogenerated charge carriers [28].

Recent reports have shown that doping of photocatalysts with heteroatoms introduces defect energy levels, which can improve the charge distribution and catalytic activity [29,30]. For example, Guo et al. [31,32] demonstrated doping of CdS nanorods with $\mathrm{P}$ or $\mathrm{Mo}$ and its role in promoting charge separation and transfer. In addition, Liu et al. [33] doped $\alpha$ $\mathrm{Fe}_{2} \mathrm{O}_{3}$ with $\mathrm{Pt}^{2+}$ and created Schottky barriers, which could effectively hinder the recombination of photogenerated electrons and holes, thereby increasing their lifetime. To date, doping of semiconductors with transition metals has been regarded as a potential strategy to improve their photocatalytic efficiency through the following mechanisms: (1) modification of the local electronic environments [34-36], (2) improvement in the separation efficiency of charge carriers [37-39], and (3) creation of new active centers [40,41]. Despite these advantages, excessive doping can decrease photocatalytic performance because of the formation of charge recombination centers [37]. In addition, the introduction of heteroatoms as dopants will inevitably reduce the apparent band gap of the catalyst and reduce its redox ability [35]. Thus, selecting a suitable catalyst and doping method is important to enhance photocatalytic performance and explore the doping mechanism of photo-

\footnotetext{
${ }^{1}$ School of Chemistry and Materials Science, Heilongjiang University, Harbin 150080, China

${ }^{2}$ College of Material Science and Chemical Engineering, Harbin Engineering University, Harbin 150001, China

${ }^{3}$ Dalian Institute of Chemical Physics, Chinese Academy of Sciences, Dalian 116023, China

${ }^{4}$ Department of Mechanical and Energy Engineering, Southern University of Science and Technology, Shenzhen 518055, China

${ }^{5}$ Shanghai Institute of Applied Physics, Chinese Academy of Sciences, Shanghai 201800, China

* Corresponding authors (emails: jbj@hlju.edu.cn (Jiang B); zhanglp@sustech.edu.cn (Zhang L))
} 
catalysis.

In this work, we demonstrate the synthesis of rod-shaped Modoped $\mathrm{In}_{2} \mathrm{O}_{3}\left(\mathrm{Mo}-\mathrm{In}_{2} \mathrm{O}_{3}\right)$ using a metal-organic framework (MOF), MIL-68(In), as the structural template. Experiments and theoretical calculations reveal that Mo with an oxidation state of +5 is incorporated into the $\operatorname{In}_{2} \mathrm{O}_{3}$ lattice to substitute $\mathrm{In}^{3+}$ ions and form Mo-O-In bonds as new reactive sites. Moreover, the interaction between Mo and In atoms can regulate the charge distribution and facilitate the transfer and separation of photogenerated charge carriers. Mo doping introduces defect energy levels below the conduction band (CB) and creates localized electron-trapping centers, which not only improve the transfer of charge carriers, but also reduce the apparent band gap, thereby enhancing the ability of $\operatorname{In}_{2} \mathrm{O}_{3}$ to use visible light.

\section{EXPERIMENTAL SECTION}

\section{Materials}

Indium(III) nitrate hydrate $\left(\operatorname{In}\left(\mathrm{NO}_{3}\right)_{3}\right)$, ammonium molybdate tetrahydrate $\left(\left(\mathrm{NH}_{4}\right)_{6} \mathrm{Mo}_{7} \mathrm{O}_{24} \cdot 4 \mathrm{H}_{2} \mathrm{O}\right)$, and 1,4-dicarboxybenzene (PTA) were all obtained from Aladdin Industrial Corporation. All chemicals were of analytical grade and used as received without further purification. Deionized water was used in the following experiments.

\section{Synthesis of In-MOF}

$\mathrm{In}\left(\mathrm{NO}_{3}\right)_{3}(0.32 \mathrm{~g})$ was dissolved in $25 \mathrm{~mL}$ of dimethylformamide (DMF) under sonication. After stirring for $30 \mathrm{~min}, 0.2 \mathrm{~g}$ of PTA was added under sonication, and then the mixture was further stirred for $20 \mathrm{~min}$. Next, the mixture was transferred to a hydrothermal kettle and placed in an oven at $120^{\circ} \mathrm{C}$ for $3 \mathrm{~h}$. The precipitate was collected by centrifugation and dried at $60^{\circ} \mathrm{C}$ in air.

\section{Synthesis of $\operatorname{In}_{2} \mathrm{O}_{3}$}

In-MOF was transferred to a muffle furnace and calcined in air at $500^{\circ} \mathrm{C}$ for $2 \mathrm{~h}$.

\section{Synthesis of bulk $\operatorname{In}_{2} \mathrm{O}_{3}$}

Indium nitrate $(1 \mathrm{mmol})$ was dissolved in $60 \mathrm{~mL}$ of deionized water. Subsequently, $3 \mathrm{mmol}$ of urea was added; the mixture was further stirred for $30 \mathrm{~min}$. Next, this mixture was transferred to a 100-mL Teflon-lined stainless-steel autoclave and then heated at $140^{\circ} \mathrm{C}$ for $10 \mathrm{~h}$. The precipitate was collected by centrifugation and washed thrice with purified water and ethanol. Finally, it was calcined in air at $500^{\circ} \mathrm{C}$ for $2 \mathrm{~h}$.

\section{Synthesis of MOF-polyoxometalate (POM)}

First, $0.1 \mathrm{~g}$ of $\left(\mathrm{NH}_{4}\right)_{6} \mathrm{Mo}_{7} \mathrm{O}_{24} \cdot 4 \mathrm{H}_{2} \mathrm{O}$ was dispersed in $1.5 \mathrm{~mL}$ of deionized water under sonication. Next, $25 \mathrm{~mL}$ of DMF was added under stirring, and the mixture was further stirred for $5 \mathrm{~min}$. Afterward, $0.32 \mathrm{~g}$ of $\operatorname{In}\left(\mathrm{NO}_{3}\right)_{3}$ was added under sonication, and then the mixture was stirred for $20 \mathrm{~min}$. Finally, PTA was added, and the mixture was agitated continuously until a yellowish precipitate was formed. The precipitate was transferred to the Teflon-lined stainless-steel autoclave and kept at $120^{\circ} \mathrm{C}$ for $3 \mathrm{~h}$.

\section{Synthesis of $\mathrm{Mo}-\mathrm{In}_{2} \mathrm{O}_{3}$}

Dried MOF-POM was transferred to a muffle furnace and calcined in air at $500^{\circ} \mathrm{C}$ for $2 \mathrm{~h}$.

\section{Synthesis of Mo-doped $\operatorname{In}_{2} \mathrm{O}_{3}$}

$\left(\mathrm{NH}_{4}\right)_{6} \mathrm{Mo}_{7} \mathrm{O}_{24} \cdot 4 \mathrm{H}_{2} \mathrm{O}(0.1 \mathrm{~g})$ and a certain amount of In-MOF were physically mixed in a mortar, and then the ground sample was calcined in air at $500^{\circ} \mathrm{C}$ for $2 \mathrm{~h}$.

\section{RESULTS AND DISCUSSION}

Mo-doped $\mathrm{In}_{2} \mathrm{O}_{3}$ (Mo- $\mathrm{In}_{2} \mathrm{O}_{3}$ ) was prepared using MIL-68(In) as the indium source and the structural template and $\left(\mathrm{NH}_{4}\right)_{6} \mathrm{Mo}_{7} \mathrm{O}_{24} \cdot 4 \mathrm{H}_{2} \mathrm{O}$ as the molybdenum source [42]. The precursors of MIL-68(In) and source of Mo were mixed to produce POM-MOF, which has the same rod-like structure as In-MOF (Fig. S1). The production of $\operatorname{In}_{2} \mathrm{O}_{3}$ and its doping with Mo were achieved simultaneously by calcining In-MOF at $500^{\circ} \mathrm{C}$ (Fig. 1a). At this temperature, $\left(\mathrm{NH}_{4}\right)_{6} \mathrm{Mo}_{7} \mathrm{O}_{24} \cdot 4 \mathrm{H}_{2} \mathrm{O}$ and POM-MOF were decomposed as verified by thermogravimetric analysis (Fig. S2). Scanning electron microscopy (SEM) images show that the $\mathrm{In}_{2} \mathrm{O}_{3}$ and $\mathrm{Mo}-\mathrm{In}_{2} \mathrm{O}_{3}$ samples are composed of micro-sized hexagonal rods (Figs S3 and S4). The adsorption isotherms of Mo- $\mathrm{In}_{2} \mathrm{O}_{3}$ and $\mathrm{In}_{2} \mathrm{O}_{3}$ present a type $\mathrm{H} 3$ hysteresis loop (Fig. S5), which indicates the presence of mesopores formed via particle aggregation. The Brunauer-Emmett-Teller method was used to calculate the specific surface area, and the result shows that the doping has negligible effect (36.1 and $35.6 \mathrm{~m}^{2} \mathrm{~g}^{-1}$ for $\mathrm{Mo}-\mathrm{In}_{2} \mathrm{O}_{3}$ and $\mathrm{In}_{2} \mathrm{O}_{3}$, respectively) [43]. However, the average pore size is decreased after doping (Fig. S6). The rod-shaped structure of Mo- $\mathrm{In}_{2} \mathrm{O}_{3}$ was also observed using transmission electron microscopy (TEM). Moreover, the TEM image shows that the structure consists of tightly connected nanoparticles, which can improve the transfer of electrons and holes (Fig. 1b and Fig. S7) [44]. The high-resolution TEM image exhibits clear lattice fringes with a spacing of $0.29 \mathrm{~nm}$ corresponding to the (222) facet of cubic $\mathrm{In}_{2} \mathrm{O}_{3}$ (PDF\#06-0416, Fig. 1c). Furthermore, individual Mo atoms are shown as bright spots in the high-angle annular dark-field (HAADF) image (Fig. 1d), indicating that Mo atoms have been doped into the crystal structure of $\mathrm{In}_{2} \mathrm{O}_{3}$ [45]. The Mo content was determined to be $0.47 \mathrm{wt} \%$ by inductively coupled plasma atomic emission spectrometry (Table S1). The Mo atoms are uniformly distributed in $\mathrm{In}_{2} \mathrm{O}_{3}$ as evidenced by elemental mapping (Fig. 1e-g) and energy-dispersive $\mathrm{X}$-ray spectroscopy (EDS, Fig. S8). In addition, a small amount of carbon and nitrogen are found by EDS.

The cubic structure of $\operatorname{In}_{2} \mathrm{O}_{3}$ was further verified by X-ray diffraction (XRD). The most intense peak in the patterns of $\mathrm{In}_{2} \mathrm{O}_{3}$ and $\mathrm{Mo}-\mathrm{In}_{2} \mathrm{O}_{3}$ is located at $30.5^{\circ}$ (Fig. 2a) [42]. In addition, given the small amount of $\mathrm{Mo}$, no additional peak was found in the pattern of Mo- $\operatorname{In}_{2} \mathrm{O}_{3}$. However, given the difference in the radius of Mo and In ions, the XRD peaks of $\mathrm{Mo}-\mathrm{In}_{2} \mathrm{O}_{3}$ were shifted compared with those of $\mathrm{In}_{2} \mathrm{O}_{3}$ (Fig. S9) [31]. Furthermore, the XRD patterns of In-MOF, POM-MOF, and $\left(\mathrm{NH}_{4}\right)_{6} \mathrm{Mo}_{7} \mathrm{O}_{24} \cdot 4 \mathrm{H}_{2} \mathrm{O}$ and the Fourier transform infrared spectra show that the addition of $\left(\mathrm{NH}_{4}\right)_{6} \mathrm{Mo}_{7} \mathrm{O}_{24} \cdot 4 \mathrm{H}_{2} \mathrm{O}$ into the precursors of MIL-68(In), namely, $\operatorname{In}\left(\mathrm{NO}_{3}\right)_{3}$ and phthalic acid, did not hinder the formation of the MOF (Figs S10 and S11) [46]. Preservation of the crystal structure of $\operatorname{In}_{2} \mathrm{O}_{3}$ after Mo doping is evident by the Raman spectra of $\operatorname{In}_{2} \mathrm{O}_{3}$ and $\mathrm{Mo}-\mathrm{In}_{2} \mathrm{O}_{3}$, which present peaks at the same Raman shifts (Fig. S12) [47].

The chemical state and electronic structure of $\mathrm{Mo}-\mathrm{In}_{2} \mathrm{O}_{3}$ were studied by X-ray photoelectron spectroscopy (XPS). The peaks at approximately 451.04 and $443.45 \mathrm{eV}$ in the high-resolution XPS In $3 \mathrm{~d}$ spectrum of $\mathrm{Mo}-\mathrm{In}_{2} \mathrm{O}_{3}$ are attributed to the $3 \mathrm{~d}_{3 / 2}$ and $3 \mathrm{~d}_{5 / 2}$ electrons of $\mathrm{In}^{3+}$, respectively (Fig. 2b) [48]. This pair of peaks is 
a

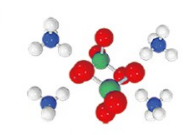

$\left(\mathrm{NH}_{4}\right)_{2} \mathrm{MoO}_{4}$

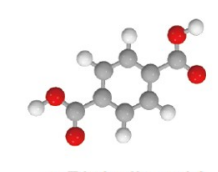

$p$-Phthalic acid

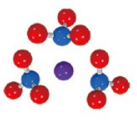

$\ln \left(\mathrm{NO}_{3}\right)_{3}$
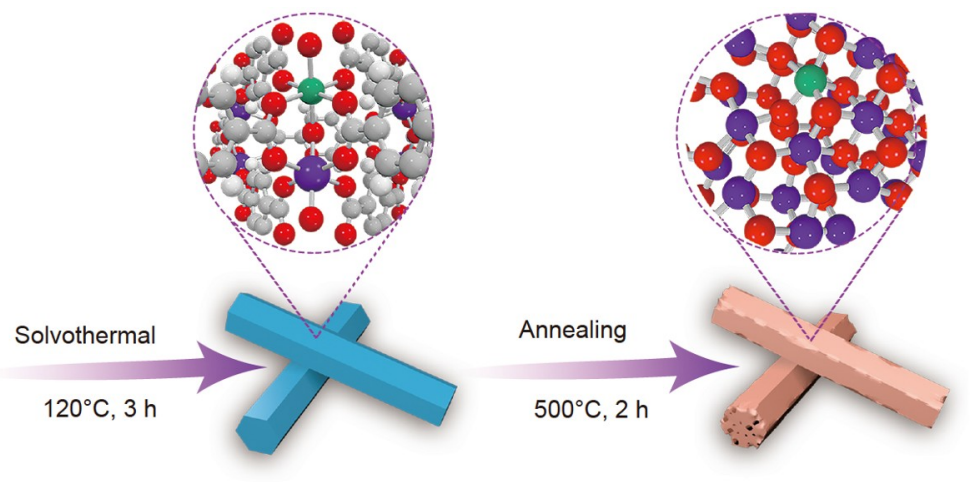

MOF-POM

$\mathrm{Mo}-\mathrm{In}_{2} \mathrm{O}_{3}$

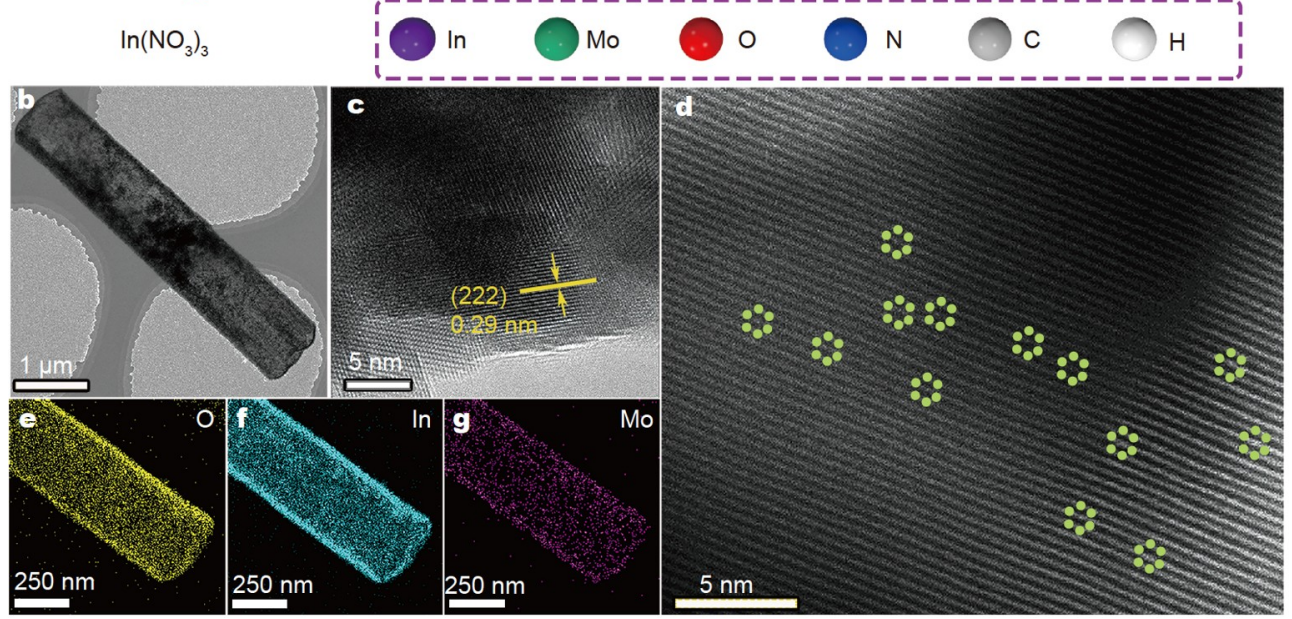

Figure 1 (a) Schematic illustration of the synthesis of micro-sized Mo- $\operatorname{In}_{2} \mathrm{O}_{3}$ hexagonal rods. (b, c) TEM and (d) HAADF- scanning TEM (STEM) images of Mo- $\mathrm{In}_{2} \mathrm{O}_{3}$; (e-g) the corresponding elemental mappings for $\mathrm{Mo}-\mathrm{In}_{2} \mathrm{O}_{3}$.

shifted to lower binding energies for $\mathrm{Mo}-\mathrm{In}_{2} \mathrm{O}_{3}$, indicating the increase in the electron density around In atoms. The XPS O 1s spectra of $\mathrm{In}_{2} \mathrm{O}_{3}$ and $\mathrm{Mo}-\mathrm{In}_{2} \mathrm{O}_{3}$ can be deconvoluted to two peaks (Fig. 2c), corresponding to the defect oxygen ( $\mathrm{O}$ defect, larger binding energy) and lattice oxygen $[49,50]$. Apart from the increase in the electron density around In, the decrease in the binding energy for the lattice oxygen caused by Mo doping indicates an electron transfer from Mo to In through $\mathrm{O}$ (i.e., the formation of Mo-O-In bonds) [42,51,52]. The presence of Mo with an oxidation state of +5 is evidenced by the XPS Mo 3d spectrum that features two peaks located at 232.03 and $235.26 \mathrm{eV}$ (Fig. 2d). These XPS results indicate that a portion of the $\mathrm{In}^{3+}$ ions have been replaced by $\mathrm{Mo}^{5+}$ ions [53].

The ultraviolet-visible (UV-vis) diffuse reflectance spectra indicate that $\operatorname{In}_{2} \mathrm{O}_{3}$ and $\mathrm{Mo}-\mathrm{In}_{2} \mathrm{O}_{3}$ can absorb visible light (Fig. S13); however, doping of $\operatorname{In}_{2} \mathrm{O}_{3}$ with Mo decreases the apparent band gap determined by Tauc plots from 2.56 to $2.43 \mathrm{eV}$ (Fig. 3a). The flat band potentials of $\mathrm{Mo}-\mathrm{In}_{2} \mathrm{O}_{3}$ and $\mathrm{In}_{2} \mathrm{O}_{3}$ relative to the $\mathrm{Ag} / \mathrm{AgCl}$ electrode reach -0.83 and $-0.92 \mathrm{~V}$ by constructing Mott-Schottky plots at frequencies of $0.8,1.0$, and $1.2 \mathrm{kHz}$ (Fig. 3b and Fig. S14) [25]. The shift of the flat band potential of $\operatorname{In}_{2} \mathrm{O}_{3}$ toward a less negative value after Mo doping has been ascribed to the formation of defect states in the band gap $[39,54]$. Considering that $\operatorname{In}_{2} \mathrm{O}_{3}$ is an n-type semiconductor, its Fermi level is close to the bottom of the CB. Hence, the potential of the $\mathrm{CB}$ minimum is approximated as the flat band potential. Consequently, the potentials of the valence band (VB) maxima of $\operatorname{In}_{2} \mathrm{O}_{3}$ and $\mathrm{Mo}-\mathrm{In}_{2} \mathrm{O}_{3}$ are 1.64 and $1.60 \mathrm{~V}$ ( $v$ s. the $\mathrm{Ag} /$ $\mathrm{AgCl}$ electrode), respectively [25]. Notably, the edges of the $\mathrm{VB}$ are also evident by XPS valence-band spectra (Fig. S15). As shown in the resultant band diagram (Fig. 3c), the introduction of Mo atoms in $\mathrm{In}_{2} \mathrm{O}_{3}$ reduces the apparent band gap and improves the ability of $\operatorname{In}_{2} \mathrm{O}_{3}$ to absorb visible light [55].

Density functional theory (DFT) calculations were conducted to investigate the electronic structure of the materials. The charge density distribution of $\operatorname{In}_{2} \mathrm{O}_{3}$ was obtained by subtracting the charge density of In and $\mathrm{O}$ atoms from the total charge density [56]. As expected, electrons are accumulated around the $\mathrm{O}$ atoms. However, the substitution of part of the In atoms by Mo atoms resulted in charge redistribution. Notably, electrons of Mo are strongly attracted by the surroundings (Fig. 3d, e). The projected density of states (PDOS) of pure $\operatorname{In}_{2} \mathrm{O}_{3}$ reveals that the valance band is primarily composed of $\mathrm{O} 2 \mathrm{p}$ orbitals, and the $\mathrm{CB}$ is composed of In $\mathrm{d}$ orbitals, which indicate that electrons of $\mathrm{O}$ are excited and then transferred to In [57]. The PDOS profile of Mo- $\mathrm{In}_{2} \mathrm{O}_{3}$ shows the presence of Mo d orbitals in the bandgap. $\mathrm{In}_{2} \mathrm{O}_{3}$ is an n-type semiconductor, and its Fermi level is located near the bottom of the CB [58]. The defect states close to the Fermi level caused by Mo doping may not only reduce the band gap to improve light absorption, but also serve as electron traps to inhibit electron-hole recombination (Fig. $3 \mathrm{f}$ and Fig. S16) [59]. Compared with $\mathrm{In}_{2} \mathrm{O}_{3}$, the d-band center of Mo- $\mathrm{In}_{2} \mathrm{O}_{3}$ moves up to larger energy, which improves electron transfer from $\mathrm{Mo}-\mathrm{In}_{2} \mathrm{O}_{3}$ to LA [60]. 

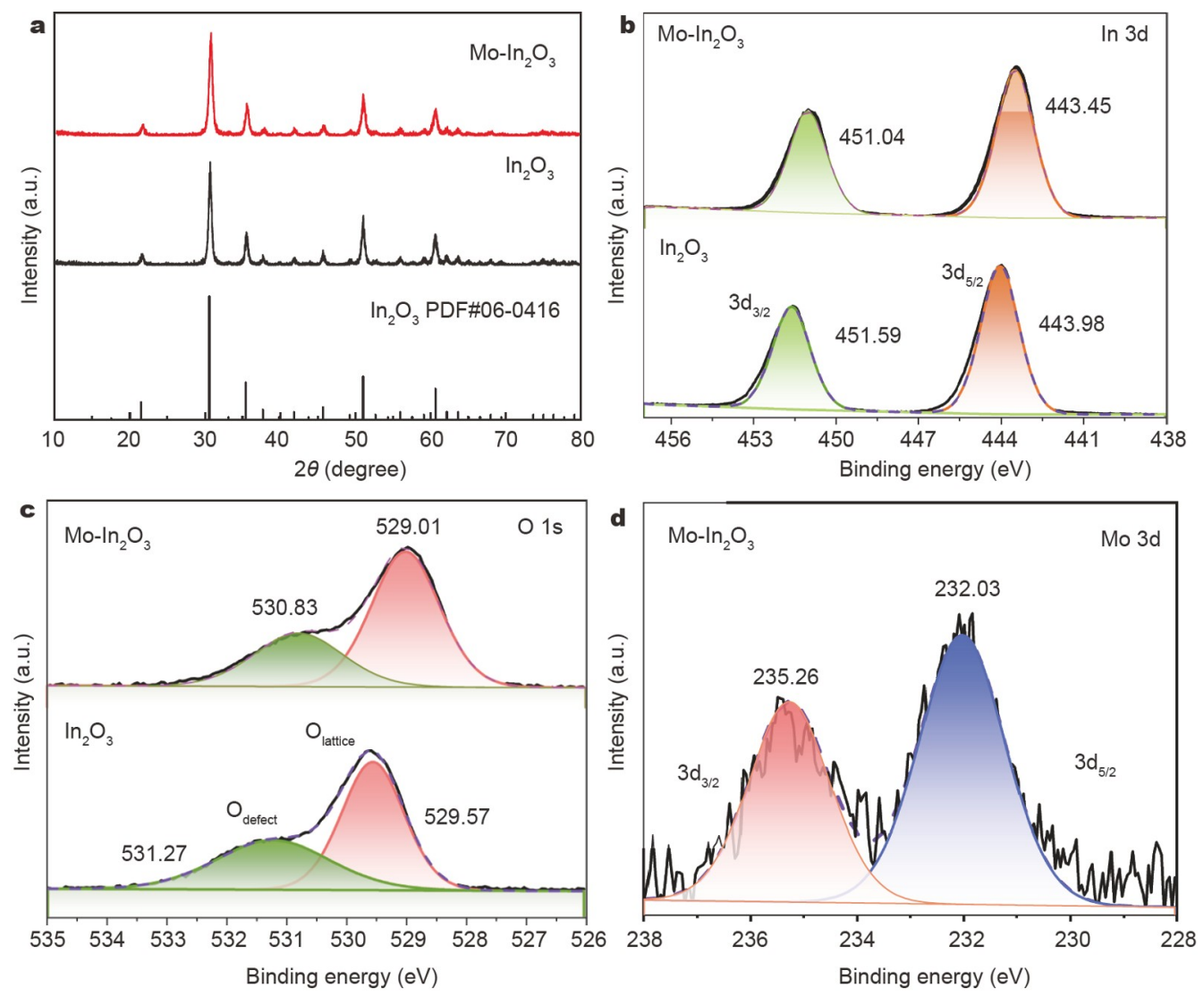

Figure 2 (a) XRD patterns of $\mathrm{In}_{2} \mathrm{O}_{3}$ and Mo- $\mathrm{In}_{2} \mathrm{O}_{3}$. High-resolution XPS spectra of (b) O 1s, (c) In 3d, and (d) Mo 3d.
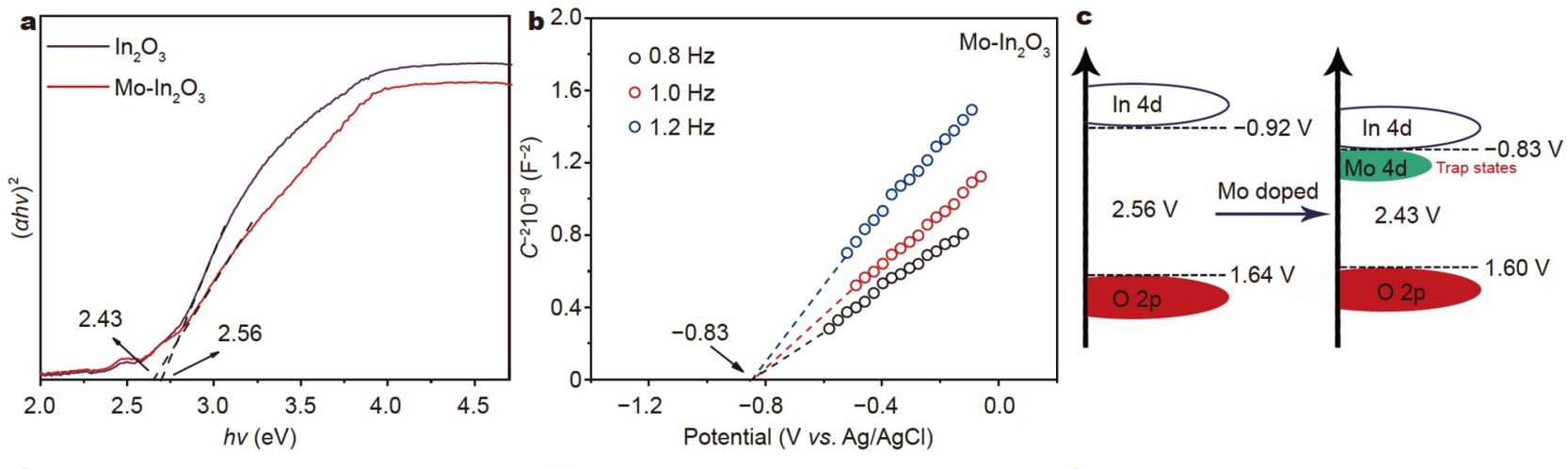

d

e

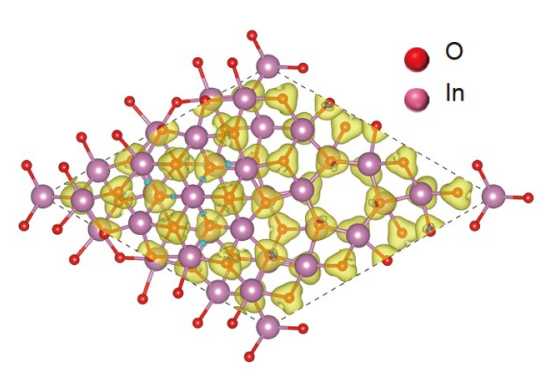

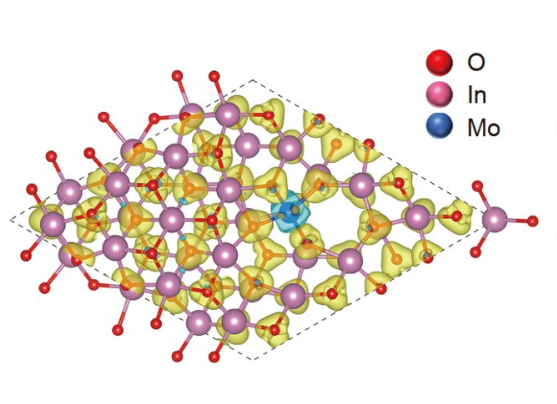

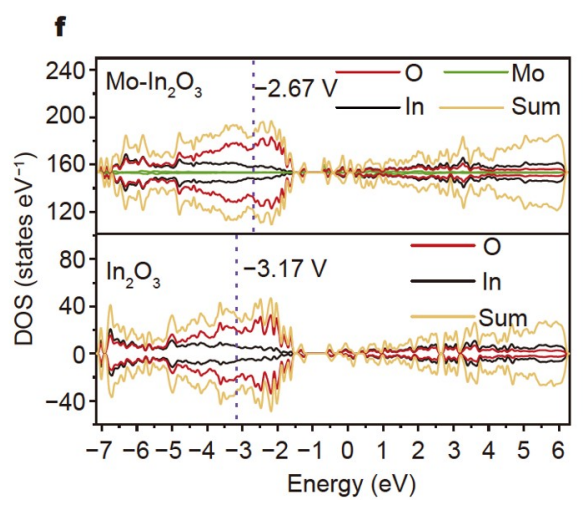

Figure 3 (a) Band gaps determined by Tauc plots of $\operatorname{In}_{2} \mathrm{O}_{3}$ and $\mathrm{Mo}-\mathrm{In}_{2} \mathrm{O}_{3}$. (b) Mott-Schottky plots of Mo- $\operatorname{In}_{2} \mathrm{O}_{3}$ at various frequencies ( $\mathrm{pH}=7$ ). (c) Band diagrams of $\operatorname{In}_{2} \mathrm{O}_{3}$ and $\mathrm{Mo}-\mathrm{In}_{2} \mathrm{O}_{3}$. (d, e) Charge density isosurface of $\operatorname{In}_{2} \mathrm{O}_{3}$ and $\mathrm{Mo}-\mathrm{In}_{2} \mathrm{O}_{3}$, in which accumulation and depletion are colored in cyan and yellow. (f) $\mathrm{PDOS}$ of $\mathrm{In}_{2} \mathrm{O}_{3}$ and $\mathrm{Mo}-\mathrm{In}_{2} \mathrm{O}_{3}$. 
Steady-state and transient-state photoluminescence (PL) spectroscopy was used to investigate the dynamics of photogenerated electrons and holes. The steady-state PL spectrum of $\mathrm{In}_{2} \mathrm{O}_{3}$ shows an emission peak at $435 \mathrm{~nm}$, which is attributed to the radiative recombination of electrons and holes. By contrast, the PL peak of $\mathrm{Mo}-\mathrm{In}_{2} \mathrm{O}_{3}$ is greatly weakened, indicating that the defect states below the $\mathrm{CB}$ of $\mathrm{In}_{2} \mathrm{O}_{3}$ serve as electron traps to inhibit electron-hole recombination (Fig. S17). Transient-state PL spectra of $\mathrm{In}_{2} \mathrm{O}_{3}$ and $\mathrm{Mo}-\mathrm{In}_{2} \mathrm{O}_{3}$ indicate that Mo doping enhances charge transport as evidenced by the short lifetime of the charge carriers in Mo- $\operatorname{In}_{2} \mathrm{O}_{3}$ during relaxation (Fig. 4a). In addition, the radius of the semicircle in the Nyquist plot of Mo$\mathrm{In}_{2} \mathrm{O}_{3}$ is smaller than that of $\operatorname{In}_{2} \mathrm{O}_{3}$ (Fig. $4 \mathrm{~b}$ ), thereby confirming the improvement in charge transfer because of the Mo doping $[61,62]$. This improvement in charge transfer was further verified by the strong photocurrent responses of $\mathrm{Mo}-\mathrm{In}_{2} \mathrm{O}_{3}$ under intermittent light irradiation (Fig. 4c). The work function of $\mathrm{In}_{2} \mathrm{O}_{3}$ and $\mathrm{Mo}-\mathrm{In}_{2} \mathrm{O}_{3}$ was determined by Kelvin probe force microscopy (Fig. 4d) [63-65]. Consequently, Mo doping reduces the work function of $\operatorname{In}_{2} \mathrm{O}_{3}$, which is in agreement with the observation that the flat potential of $\operatorname{In}_{2} \mathrm{O}_{3}$ is more negative than that of $\mathrm{Mo}-\mathrm{In}_{2} \mathrm{O}_{3}$.

Mo- $\mathrm{In}_{2} \mathrm{O}_{3}$ was used as a photocatalyst in converting LA into an amino acid (i.e., alanine) because of its good physicochemical properties. Control experiments (Table 1, entries 1-6) revealed that the reaction must be conducted at $50^{\circ} \mathrm{C}$ in a nitrogen atmosphere in the presence of ammonia to achieve the optimal conversion rate and selectivity, which was confirmed by gas chromatography-mass spectrometry (GC-MS) (Fig. S18). In addition, the conversion rate increases with time, and it reaches the maximum at a reaction time of $4 \mathrm{~h}$ (Fig. S19). Furthermore, different amounts of $\left(\mathrm{NH}_{4}\right)_{6} \mathrm{Mo}_{7} \mathrm{O}_{24} \cdot 4 \mathrm{H}_{2} \mathrm{O}$ were added during synthesis to determine the amount of Mo favorable for the reaction of LA (Table S2). Under the optimal reaction conditions and simulated sunlight irradiation, Mo- $\mathrm{In}_{2} \mathrm{O}_{3}$ achieved a high LA-to-alanine conversion rate of $81 \%$ with a selectivity of $91 \%$ (Table 1, entry 9). Therefore, Mo- $\operatorname{In}_{2} \mathrm{O}_{3}$ is an effective heterogeneous catalyst for this reaction (Table S3). By contrast, neither bulk $\mathrm{In}_{2} \mathrm{O}_{3}$ (Table 1 , entry 7) nor hexagonal tubular $\operatorname{In}_{2} \mathrm{O}_{3}$ (Table 1, entry 8) can induce comparable conversion efficiency, which indicates the importance of doped Mo atoms and the neglectable effect of the morphology of $\mathrm{In}_{2} \mathrm{O}_{3}$. The role of Mo doping is further supported by the low conversion rates of ground Mo- $\mathrm{In}_{2} \mathrm{O}_{3}$ (Table 1, entry 10) and the physical mixture of $\mathrm{In}_{2} \mathrm{O}_{3}$ and $\left(\mathrm{NH}_{4}\right)_{6} \mathrm{Mo}_{7} \mathrm{O}_{24} \cdot 4 \mathrm{H}_{2} \mathrm{O}$ (POM; Table 1, entry 11 ).

Apart from the conversion rate and selectivity, the reaction rate is also important. On the one hand, the reaction rate can be measured on the basis of LA conversion, and it is as high as $0.407 \mathrm{mmol} \mathrm{h}^{-1}$ for Mo- $\operatorname{In}_{2} \mathrm{O}_{3}$, which is about 1.6 times that of $\mathrm{In}_{2} \mathrm{O}_{3}\left(0.254 \mathrm{mmol} \mathrm{h}^{-1}\right.$, Fig. 5a). On the other hand, the reaction rate can be assessed on the basis of alanine production, which is 0.369 and $0.186 \mathrm{mmol} \mathrm{h}^{-1}$ for $\mathrm{Mo}-\mathrm{In}_{2} \mathrm{O}_{3}$ and $\mathrm{In}_{2} \mathrm{O}_{3}$, respectively (Fig. 5b). In addition, the photocatalyst showed great stability during the reaction. As shown in Fig. $5 c$, after five reaction cycles (corresponding to a total reaction time of $20 \mathrm{~h}$ ), the conversion rate and selectivity did not decrease significantly.
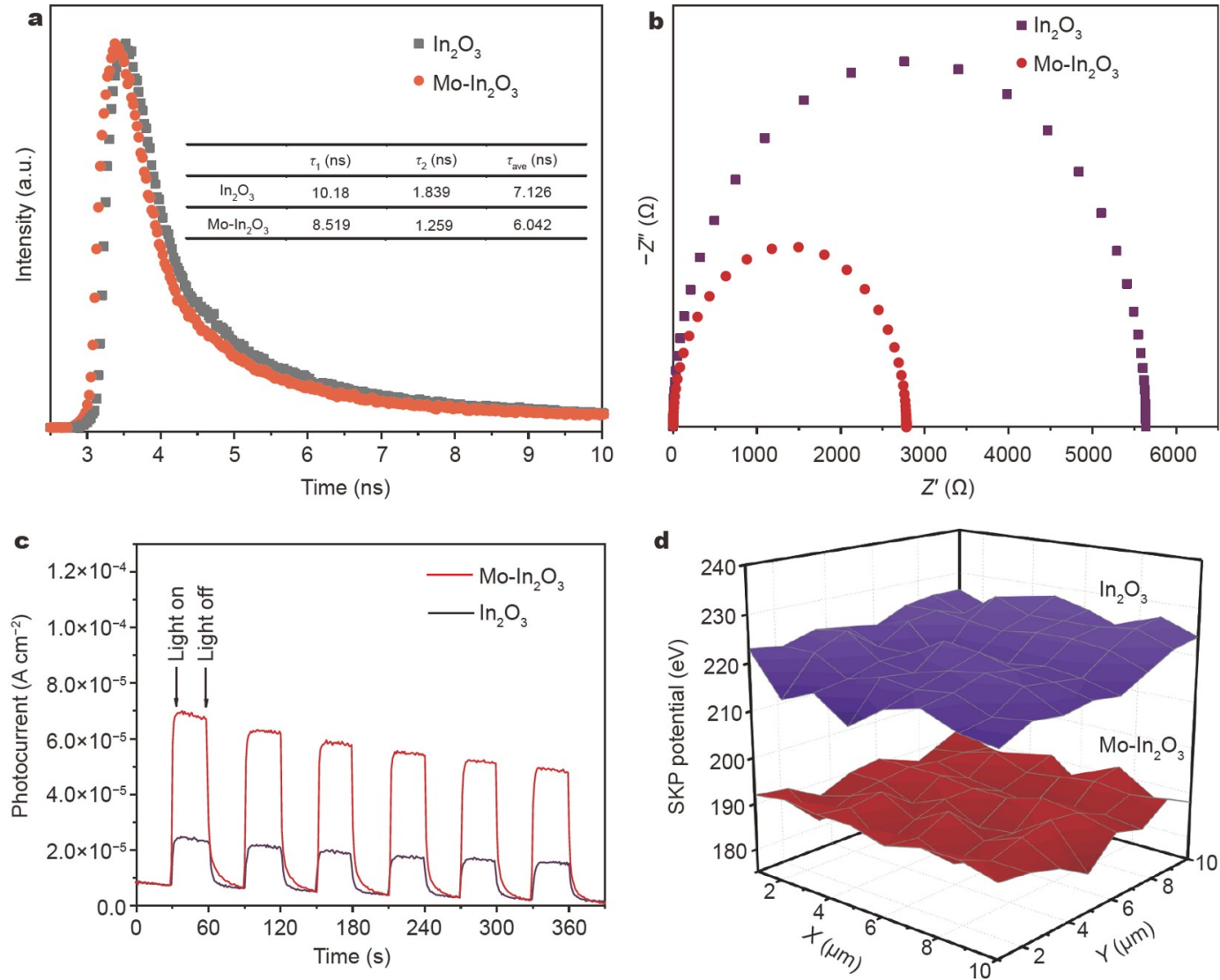

Figure 4 (a) Transient-state PL spectra; (b) Nyquist plots; (c) time-resolved photocurrent responses; (d) scanning Kelvin probe mappings (SKP) of In $\mathrm{O}_{3}$ and $\mathrm{Mo}-\mathrm{In}_{2} \mathrm{O}_{3}$. 
Table 1 Experimental conditions and results of LA-to-alanine conversion

\begin{tabular}{|c|c|c|c|c|c|c|c|c|}
\hline Entry & Catalyst & $\mathrm{NH}_{3} \cdot \mathrm{H}_{2} \mathrm{O}$ & Temperature $\left({ }^{\circ} \mathrm{C}\right)$ & $\mathrm{N}_{2}$ & Light & Scavenger & Conversion rate $(\%)$ & Selectivity (\%) \\
\hline 1 & - & + & 50 & + & + & & 0 & 0 \\
\hline 2 & $\mathrm{Mo}-\mathrm{In}_{2} \mathrm{O}_{3}$ & + & 50 & + & - & & 15 & 37 \\
\hline 3 & $\mathrm{Mo}-\mathrm{In}_{2} \mathrm{O}_{3}$ & + & - & + & + & & 29 & 25 \\
\hline 4 & $\mathrm{Mo}-\mathrm{In}_{2} \mathrm{O}_{3}$ & + & 50 & - & + & & 13 & 21 \\
\hline 5 & $\mathrm{Mo}-\mathrm{In}_{2} \mathrm{O}_{3}$ & - & 50 & + & + & & 0 & 0 \\
\hline 6 & Mo- $\mathrm{In}_{2} \mathrm{O}_{3}$ & - & 50 & - & + & & 0 & 0 \\
\hline 7 & $\mathrm{In}_{2} \mathrm{O}_{3}$ & + & 50 & + & + & & 35 & 45 \\
\hline 8 & $\mathrm{In}_{2} \mathrm{O}_{3}$ & + & 50 & + & + & & 34 & 36 \\
\hline 9 & $\mathrm{Mo}-\mathrm{In}_{2} \mathrm{O}_{3}$ & + & 50 & + & + & & 81 & 91 \\
\hline 10 & Mo- $\mathrm{In}_{2} \mathrm{O}_{3}$ & + & 50 & + & + & & 30 & 52 \\
\hline 11 & $\mathrm{In}_{2} \mathrm{O}_{3}+\mathrm{POM}$ & + & 50 & + & + & & 13 & 43 \\
\hline 12 & $\mathrm{Mo}-\mathrm{In}_{2} \mathrm{O}_{3}$ & + & 50 & + & + & $\mathrm{C}_{6} \mathrm{H}_{5} \mathrm{NO}_{2}$ & 20 & 47 \\
\hline 13 & Mo- $\operatorname{In}_{2} \mathrm{O}_{3}$ & + & 50 & + & + & IPA & 45 & 38 \\
\hline
\end{tabular}
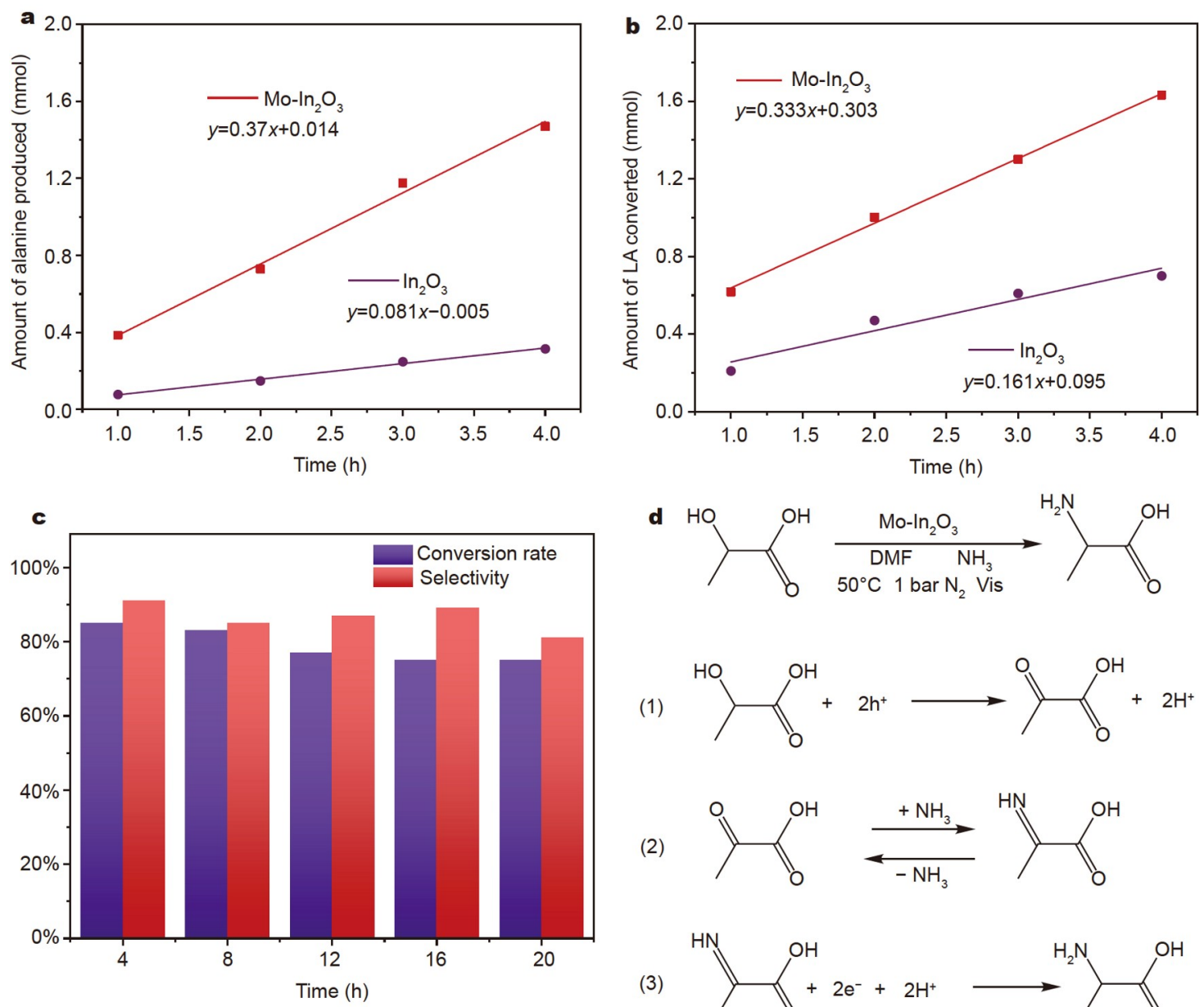

(1)

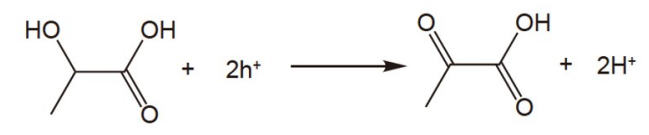

(2)

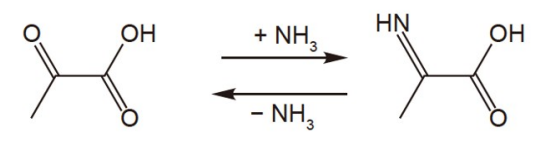

(3)

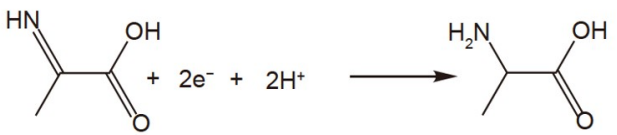

Figure 5 Amounts of (a) LA converted and (b) alanine produced as a function of time for $\operatorname{In}_{2} \mathrm{O}_{3}$ and $\mathrm{Mo}-\mathrm{In}_{2} \mathrm{O}_{3}$; (c) conversion rate and selectivity of five consecutive $4 \mathrm{~h}$ reactions; (d) mechanisms of the conversion of LA to alanine over $\mathrm{Mo}-\mathrm{In}_{2} \mathrm{O}_{3}$.

Studies of the recycled Mo- $\operatorname{In}_{2} \mathrm{O}_{3}$ catalyst by using SEM and XRD indicate that the morphology and crystallinity are not altered (Figs S20 and S21).

Electron and hole scavengers were selectively added to the reaction system to determine the active species responsible for
LA-to-alanine conversion and understand the reaction mechanism. When nitrobenzene (an electron scavenger) was added, the conversion rate dropped from $81 \%$ to $20 \%$ (Table 1 , entry 12). This result indicats the important role of photogenerated electrons in the reaction, although such electrons are 
not involved in any change in the oxidation state. Similarly, the addition of isopropanol (IPA, a hole scavenger) also led to a decrease in the conversion rate from $81 \%$ to $45 \%$ (Table 1 , entry 13). By combining these experimental results with previous reports, we propose a reaction mechanism (Fig. 5d). In brief, LA molecules adsorbed on $\mathrm{Mo}-\mathrm{In}_{2} \mathrm{O}_{3}$ are first transformed to pyruvic acid after receiving holes from the photocatalyst. Next, the latter molecules react with $\mathrm{NH}_{3}$, forming imine molecules. Finally, the imine is reduced to alanine by the photogenerated electrons in $\mathrm{Mo}-\mathrm{In}_{2} \mathrm{O}_{3}$ [23].

\section{CONCLUSIONS}

Mo- $\operatorname{In}_{2} \mathrm{O}_{3}$ with a rod-like structure was synthesized by a simple solvothermal method, followed by pyrolysis using MIL-68(In) as the In source and the structural template and $\left(\mathrm{NH}_{4}\right)_{6} \mathrm{Mo}_{7} \mathrm{O}_{24}$. $4 \mathrm{H}_{2} \mathrm{O}$ as the Mo source. Under visible-light irradiation, Mo$\mathrm{In}_{2} \mathrm{O}_{3}$ effectively catalyzed the conversion of LA into alanine, reaching a conversion reaction rate of up to $0.407 \mathrm{mmol} \mathrm{h}^{-1}$, which was about 1.6 times that of $\operatorname{In}_{2} \mathrm{O}_{3}\left(0.254 \mathrm{mmol} \mathrm{h}^{-1}\right)$. From the perspective of alanine production, the reaction rate of Mo$\mathrm{In}_{2} \mathrm{O}_{3}\left(0.369 \mathrm{mmol} \mathrm{h}^{-1}\right)$ was about two times that of $\mathrm{In}_{2} \mathrm{O}_{3}$ $\left(0.186 \mathrm{mmol} \mathrm{h}^{-1}\right)$ because of the good reaction selectivity of the former photocatalyst. The excellent photocatalytic performance of $\mathrm{Mo}-\mathrm{In}_{2} \mathrm{O}_{3}$ was attributed to the enhancement in bulk and interfacial charge transfer as a result of Mo doping revealed by PL spectroscopy, electrochemical impedance spectroscopy, photocurrent spectroscopy, and DFT calculations. This work demonstrates the great potential of a well-developed technology for the synthesis of an amino acid, which may be used to develop more photocatalysts for the production of other amino acids.

\section{Received 2 October 2021; accepted 24 November 2021; published online 27 December 2021}

1 Patel RN. Biocatalytic synthesis of chiral alcohols and amino acids for development of pharmaceuticals. Biomolecules, 2013, 3: 741-777

2 Lee J, Schwarz KJ, Kim DS, et al. Ribosome-mediated polymerization of long chain carbon and cyclic amino acids into peptides in vitro. Nat Commun, 2020, 11: 4304

3 Qiu L, Lv P, Zhao C, et al. Electrochemical detection of organophosphorus pesticides based on amino acids conjugated nanoenzyme modified electrodes. Sens Actuat B-Chem, 2019, 286: 386-393

$4 \mathrm{Wu}$ G, Fang YZ, Yang S, et al. Glutathione metabolism and its implications for health. J Nutr, 2004, 134: 489-492

$5 \mathrm{Hu} \mathrm{X}$, Guo F. Amino acid sensing in metabolic homeostasis and health. Endocrine Rev, 2021, 42: 56-76

6 Le Couteur DG, Solon-Biet SM, Cogger VC, et al. Branched chain amino acids, aging and age-related health. Ageing Res Rev, 2020, 64: 101198

7 Zuend SJ, Coughlin MP, Lalonde MP, et al. Scaleable catalytic asymmetric Strecker syntheses of unnatural $\alpha$-amino acids. Nature, 2009, 461: 968-970

8 Yan H, Suk Oh J, Lee JW, et al. Scalable organocatalytic asymmetric strecker reactions catalysed by a chiral cyanide generator. Nat Commun, 2012, 3: 1212

9 Wang Y, Furukawa S, Song S, et al. Catalytic production of alanine from waste glycerol. Angew Chem Int Ed, 2020, 59: 2289-2293

10 Deng W, Wang Y, Zhang S, et al. Catalytic amino acid production from biomass-derived intermediates. Proc Natl Acad Sci USA, 2018, 115: 5093-5098

11 Liu G, Wright MM, Zhao Q, et al. Catalytic pyrolysis of amino acids: Comparison of aliphatic amino acid and cyclic amino acid. Energy Convers Manage, 2016, 112: 220-225

12 Luo N, Wang M, Li H, et al. Photocatalytic oxidation-hydrogenolysis of lignin $\beta-\mathrm{O}-4$ models via a dual light wavelength switching strategy. ACS
Catal, 2016, 6: 7716-7721

13 Marina N, Lanterna AE, Scaiano JC. Expanding the color space in the two-color heterogeneous photocatalysis of Ullmann C-C coupling reactions. ACS Catal, 2018, 8: 7593-7597

14 Fu Y, Zheng M, Li Q, et al. Interfacial engineering by creating Cu-based ternary heterostructures on $\mathrm{C}_{3} \mathrm{~N}_{4}$ tubes towards enhanced photocatalytic oxidative coupling of benzylamines. RSC Adv, 2020, 10: $28059-28065$

15 Xiao Y, Tian G, Li W, et al. Molecule self-assembly synthesis of porous few-layer carbon nitride for highly efficient photoredox catalysis. J Am Chem Soc, 2019, 141: 2508-2515

16 Xiao X, Gao Y, Zhang L, et al. A promoted charge separation/transfer system from $\mathrm{Cu}$ single atoms and $\mathrm{C}_{3} \mathrm{~N}_{4}$ layers for efficient photocatalysis. Adv Mater, 2020, 32: 2003082

17 Li Q, Zhang L, Liu J, et al. Porous carbon nitride thin strip: Precise carbon doping regulating delocalized $\pi$-electron induces elevated photocatalytic hydrogen evolution. Small, 2021, 17: 2006622

18 Wu B, Zhang L, Jiang B, et al. Ultrathin porous carbon nitride bundles with an adjustable energy band structure toward simultaneous solar photocatalytic water splitting and selective phenylcarbinol oxidation. Angew Chem Int Ed, 2021, 60: 4815-4822

19 Xia Y, Cheng B, Fan J, et al. Near-infrared absorbing 2D/3D ZnIn ${ }_{2} \mathrm{~S}_{4} / \mathrm{N}$ doped graphene photocatalyst for highly efficient $\mathrm{CO}_{2}$ capture and photocatalytic reduction. Sci China Mater, 2020, 63: 552-565

20 Wan Z, Mao Q, Chen Q. Proton-dependent photocatalytic dehalogenation activities caused by oxygen vacancies of $\operatorname{In}_{2} \mathrm{O}_{3}$. Chem Eng J, 2021, 403: 126389

21 Xue F, Miao C, Yue Y, et al. Direct conversion of bio-ethanol to propylene in high yield over the composite of $\operatorname{In}_{2} \mathrm{O}_{3}$ and zeolite beta. Green Chem, 2017, 19: 5582-5590

22 Kobielusz M, Mikrut P, Macyk W, et al. Chapter three-photocatalytic synthesis of chemicals. Adv Inorg Chem, 2018, 72: 93-144

23 Song $\mathrm{S}$, Qu J, Han $\mathrm{P}$, et al. Visible-light-driven amino acids production from biomass-based feedstocks over ultrathin CdS nanosheets. Nat Commun, 2020, 11: 4899

24 Lozano O, Chen QY, Wadekar PV, et al. Factors limiting the doping efficiency of transparent conductors: A case study of Nb-doped $\mathrm{In}_{2} \mathrm{O}_{3}$ epitaxial thin-films. Sol Energy Mater Sol Cells, 2013, 113: 171-178

25 Di Quarto F, Sunseri C, Piazza S, et al. Semiempirical correlation between optical band gap values of oxides and the difference of electronegativity of the elements. Its importance for a quantitative use of photocurrent spectroscopy in corrosion studies. J Phys Chem B, 1997, 101: $2519-2525$

$26 \mathrm{Ng} \mathrm{C}$, Yun JH, Tan HL, et al. A dual-electrolyte system for photoelectrochemical hydrogen generation using $\mathrm{CuInS}_{2}-\mathrm{In}_{2} \mathrm{O}_{3}-\mathrm{TiO}_{2}$ nanotube array thin film. Sci China Mater, 2018, 61: 895-904

27 Wang J, Liu CY, Senftle TP, et al. Variation in the $\operatorname{In}_{2} \mathrm{O}_{3}$ crystal phase alters catalytic performance toward the reverse water gas shift reaction. ACS Catal, 2019, 10: 3264-3273

28 Reyes-Gil KR, Reyes-García EA, Raftery D. Nitrogen-doped $\operatorname{In}_{2} \mathrm{O}_{3}$ thin film electrodes for photocatalytic water splitting. J Phys Chem C, 2007, 111: 14579-14588

29 Odaka $\mathrm{H}$, Shigesato Y, Murakami T, et al. Electronic structure analyses of Sn-doped $\mathrm{In}_{2} \mathrm{O}_{3}$. Jpn J Appl Phys, 2001, 40: 3231-3235

30 Peng C, Song L, Wang L, et al. Effect of surface charge distribution of phosphorus-doped $\mathrm{MoS}_{2}$ on hydrogen evolution reaction. ACS Appl Energy Mater, 2021, 4: 4887-4896

31 Guo C, Li L, Chen F, et al. One-step phosphorization preparation of gradient-P-doped CdS/CoP hybrid nanorods having multiple channel charge separation for photocatalytic reduction of water. J Colloid Interface Sci, 2021, 596: 431-441

32 Guo C, Tian K, Wang L, et al. Approach of Fermi level and electrontrap level in cadmium sulfide nanorods via molybdenum doping with enhanced carrier separation for boosted photocatalytic hydrogen production. J Colloid Interface Sci, 2021, 583: 661-671

33 Liu H, Tian K, Ning J, et al. One-step solvothermal formation of $\mathrm{Pt}$ nanoparticles decorated $\mathrm{Pt}^{2+}$-doped $\alpha-\mathrm{Fe}_{2} \mathrm{O}_{3}$ nanoplates with enhanced photocatalytic $\mathrm{O}_{2}$ evolution. ACS Catal, 2019, 9: 1211-1219

34 Twilton J, Le C, Zhang $\mathrm{P}$, et al. The merger of transition metal and 
photocatalysis. Nat Rev Chem, 2017, 1: 0052

35 Li D, Zhang W, Zeng J, et al. Nickel-doped $\mathrm{Co}_{4} \mathrm{~N}$ nanowire bundles as efficient electrocatalysts for oxygen evolution reaction. Sci China Mater, 2021, 64: 1889-1899

36 Hou J, Cao S, Sun Y, et al. Atomically thin mesoporous $\operatorname{In}_{2} \mathrm{O}_{3-x} / \operatorname{In}_{2} \mathrm{~S}_{3}$ lateral heterostructures enabling robust broadband-light photo-electrochemical water splitting. Adv Energy Mater, 2018, 8: 1701114

37 Hoang K, Latouche C, Jobic S. Defect energy levels and persistent luminescence in Cu-doped ZnS. Comput Mater Sci, 2019, 163: 63-67

38 Liu B, Li Z, Zhao X. Correlation of electron transport and photocatalysis of nanocrystalline clusters studied by Monte-Carlo continuity random walking. Phys Chem Chem Phys, 2015, 17: 5265-5273

39 Li L, Huang Y, An C, et al. Lightweight hydrides nanocomposites for hydrogen storage: Challenges, progress and prospects. Sci China Mater, 2019, 62: 1597-1625

40 Zhang Z, Wu Q, Johnson G, et al. Generalized synthetic strategy for transition-metal-doped brookite-phase $\mathrm{TiO}_{2}$ nanorods. J Am Chem Soc, 2019, 141: 16548-16552

41 Gonçalves DAF, Alvim RPR, Bicalho HA, et al. Highly dispersed Modoped graphite carbon nitride: Potential application as oxidation catalyst with hydrogen peroxide. New J Chem, 2018, 42: 5720-5727

42 Cai Z, Dai J, Li W, et al. Pd supported on MIL-68(In)-derived $\mathrm{In}_{2} \mathrm{O}_{3}$ nanotubes as superior catalysts to boost $\mathrm{CO}_{2}$ hydrogenation to methanol. ACS Catal, 2020, 10: 13275-13289

43 Han L, Jing F, zhang J, et al. Environment friendly and remarkably efficient photocatalytic hydrogen evolution based on metal organic framework derived hexagonal/cubic $\operatorname{In}_{2} \mathrm{O}_{3}$ phase-junction. Appl Catal B-Environ, 2021, 282: 119602

44 Li R, Sun L, Zhan W, et al. Engineering an effective noble-metal-free photocatalyst for hydrogen evolution: Hollow hexagonal porous microrods assembled from $\mathrm{In}_{2} \mathrm{O}_{3} @$ carbon core-shell nanoparticles. J Mater Chem A, 2018, 6: 15747-15754

45 Fei H, Dong J, Arellano-Jiménez MJ, et al. Atomic cobalt on nitrogendoped graphene for hydrogen generation. Nat Commun, 2015, 6: 8668

46 Swallow JEN, Williamson BAD, Sathasivam S, et al. Resonant doping for high mobility transparent conductors: The case of Mo-doped $\operatorname{In}_{2} \mathrm{O}_{3}$. Mater Horiz, 2020, 7: 236-243

47 Duan $\mathrm{H}$, Wang Y, Li S, et al. Controllable synthesis of Ho-doped $\operatorname{In}_{2} \mathrm{O}_{3}$ porous nanotubes by electrospinning and their application as an ethanol gas sensor. J Mater Sci, 2018, 53: 3267-3279

48 Yan $\mathrm{T}$, Li N, Wang $\mathrm{L}$, et al. Bismuth atom tailoring of indium oxide surface frustrated Lewis pairs boosts heterogeneous $\mathrm{CO}_{2}$ photocatalytic hydrogenation. Nat Commun, 2020, 11: 6095

49 Li L, Guo C, Ning J, et al. Oxygen-vacancy-assisted construction of $\mathrm{FeOOH} / \mathrm{CdS}$ heterostructure as an efficient bifunctional photocatalyst for $\mathrm{CO}_{2}$ conversion and water oxidation. Appl Catal B-Environ, 2021, 293: 120203

50 Zhang H, Wang L, Guo C, et al. Enhanced photoactivity and photostability for visible-light-driven water oxidation over $\mathrm{BiFeO}_{3}$ porous nanotubes by modification of Mo doping and carbon nanocoating. ChemNanoMat, 2020, 6: 1325-1331

51 Pawar KK, Chaudhary LS, Mali SS, et al. $\mathrm{In}_{2} \mathrm{O}_{3}$ nanocapsules for rapid photodegradation of crystal violet dye under sunlight. J Colloid Interface Sci, 2020, 561: 287-297

52 Liu D, Wang J, Lu J, et al. Direct synthesis of metal-doped phosphorene with enhanced electrocatalytic hydrogen evolution. Small Methods, 2019, 3: 1900083

53 Zhu L, Nuo Peh CK, Zhu T, et al. Bifunctional 2D-on-2D $\mathrm{MoO}_{3}$ nanobelt $/ \mathrm{Ni}(\mathrm{OH})_{2}$ nanosheets for supercapacitor-driven electrochromic energy storage. J Mater Chem A, 2017, 5: 8343-8351

54 Xie J, Liu W, Xin J, et al. Dual effect in fluorine-doped hematite nanocrystals for efficient water oxidation. ChemSusChem, 2017, 10: 4465-4471

55 Qi Y, Jiang J, Liang X, et al. Fabrication of black $\operatorname{In}_{2} \mathrm{O}_{3}$ with dense oxygen vacancy through dual functional carbon doping for enhancing photothermal $\mathrm{CO}_{2}$ hydrogenation. Adv Funct Mater, 2021, 31: 2100908

56 King PDC, Veal TD, Payne DJ, et al. Surface electron accumulation and the charge neutrality level in $\mathrm{In}_{2} \mathrm{O}_{3}$. Phys Rev Lett, 2008, 101: 116808

57 Odaka $\mathrm{H}$, Iwata $\mathrm{S}$, Taga $\mathrm{N}$, et al. Study on electronic structure and optoelectronic properties of indium oxide by first-principles calculations. Jpn J Appl Phys, 1997, 36: 5551-5554

58 Shi R, Ye HF, Liang F, et al. Interstitial P-doped CdS with long-lived photogenerated electrons for photocatalytic water splitting without sacrificial agents. Adv Mater, 2018, 30: 1705941

59 Shi JW, Sun D, Zou Y, et al. Trap-level-tunable Se doped CdS quantum dots with excellent hydrogen evolution performance without co-catalyst. Chem Eng J, 2019, 364: 11-19

60 Xu J, Liu JB, Liu BX, et al. Design of n-type transparent conducting oxides: The case of transition metal doping in $\operatorname{In}_{2} \mathrm{O}_{3}$. Adv Electron Mater, 2018, 4: 1700553

61 Li L, Guo C, Shen J, et al. Construction of sugar-gourd-shaped $\mathrm{CdS} / \mathrm{Co}_{1-x} \mathrm{~S}$ hollow hetero-nanostructure as an efficient Z-scheme photocatalyst for hydrogen generation. Chem Eng J, 2020, 400: 125925

62 Niu H, Liu Y, Mao B, et al. In-situ embedding MOFs-derived copper sulfide polyhedrons in carbon nanotube networks for hybrid supercapacitor with superior energy density. Electrochim Acta, 2020, 329: 135130

63 Kang Z, Si H, Shi M, et al. Kelvin probe force microscopy for perovskite solar cells. Sci China Mater, 2019, 62: 776-789

64 Zhang L, Ran J, Qiao SZ, et al. Characterization of semiconductor photocatalysts. Chem Soc Rev, 2019, 48: 5184-5206

65 Zhang N, Jalil A, Wu D, et al. Refining defect states in $\mathrm{W}_{18} \mathrm{O}_{49}$ by Mo doping: A strategy for tuning $\mathrm{N}_{2}$ activation towards solar-driven nitrogen fixation. J Am Chem Soc, 2018, 140: 9434-9443

Acknowledgements This work was supported by the National Natural Science Foundation of China (21771061), and the Outstanding Youth Fund of Heilongjiang Province (JQ 2020B002). Zhang L is thankful to the support of the SUSTech Presidential Postdoctoral Fellowship. The work was carried out at LvLiang Cloud Computing Center of China, and the calculations were performed on TianHe-2.

Author contributions Zheng M and Jiang B designed and performed the experiments and wrote the paper; Li Q provided the experiment guidance and theoretical calculation; Liu M conducted the article modification; Liu J supplied part of the experimental characterization; Zhao C and Xiao X provided the experiment guidance; Wang $\mathrm{H}$ revised this paper; Zhou J provided theoretical calculation copyright support; Zheng $M$ wrote the paper with support from Jiang B and Zhang L. All authors contributed to the general discussion.

Conflict of interest The authors declare that they have no conflict of interest.

Supplementary information Experimental details and supporting data are available in the online version of the paper.

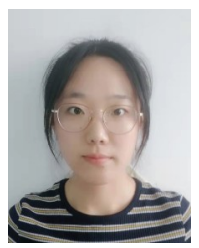

Mang Zheng is now a postgraduate at the School of Chemistry and Materials Science, Heilongjiang University. Her current research interests include photocatalytic materials and biomass conversion technology. 


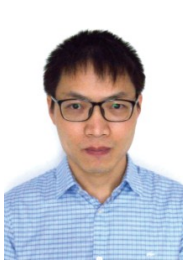

Liping Zhang received his BSc degree in chemistry from Nanjing University of Aeronautics and Astronautics in 2012 and $\mathrm{PhD}$ degree in chemistry from Kent State University in 2018. At present, he is a postdoctoral researcher at the Department of Mechanical and Energy Engineering, Southern University of Science and Technology, supported by SUSTech Presidential Postdoctoral Fellowship. His research interests include the development of nanomaterials for environmental and energy-related applications.

Baojiang Jiang received his BSc degree in 2001 from

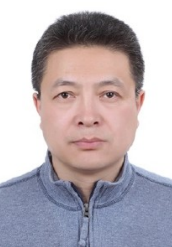
Heilongjiang University. In 2012, he received his $\mathrm{PhD}$ degree from Harbin Engineering University. He became a full professor in 2016 at Heilongjiang University. His recent research interests include organic/inorganic semiconductor photocatalytic materials for renewable clean energy and environmental protection applications.

\section{氧化铟表面构建Mo单原子活性位点用于光催化合成 氨基酸}

郑芒 ${ }^{1}$, 李琪 ${ }^{2}$, 刘明洋 ${ }^{2}$, 刘佳男 ${ }^{1}$, 赵陈 ${ }^{3}$, 肖旭东 ${ }^{1}$, 王洪丽 ${ }^{1}$, 周靖 ${ }^{5}$, 张莉平 $4^{*}$, 蒋保江 ${ }^{1^{*}}$

摘要 $\mathrm{In}_{2} \mathrm{O}_{3}$ 作为一种 $\mathrm{n}$ 型半导体, 被认为是合成氨基酸最有前途的光催 化剂之一, 然而 $\mathrm{In}_{2} \mathrm{O}_{3}$ 自身在光生电荷动力学方面存在不足. 我们通过 一步溶剂热和㷽烧法合成了具有多孔棒状结构的 Mo 原子掺杂 $\mathrm{In}_{2} \mathrm{O}_{3}$ $\left(\mathrm{Mo}-\mathrm{In}_{2} \mathrm{O}_{3}\right)$. 在可见光照射下, 将 $\mathrm{Mo}-\mathrm{In}_{2} \mathrm{O}_{3}$ 用于乳酸转化为丙氨酸的反 应, 实现了 $81 \%$ 的转化率和 $91 \%$ 的选择性. 光谱技术和密度泛函理论计 算表明, $\mathrm{Mo}$ 原子引入了略低于 $\mathrm{In}_{2} \mathrm{O}_{3}$ 导带的缺陷能级, 改善了光生电子空穴对的分离效率. 此外, $\mathrm{In}_{2} \mathrm{O}_{3}$ 表面上的 $\mathrm{Mo}$ 原子形成新的吸附和反应 活性中心, 可显著提高催化反应速率. 本工作为开发过渡金属单原子修 饰的半导体光催化剂应用于氨基酸生产提供了理论基础. 